\title{
U.S. V. Brendt Christsensen: Jurisdictional, Psychosocial and Cross-cultural Issues
}

\author{
Janet Brewer, JD, PsyD \\ Governors State University, Illinois, USA
}

\begin{abstract}
This paper discusses the kidnapping and murder of Yingying Zhang, a visiting Chinese scholar at the University of Illinois at Urbana-Champaign, in Urbana, Illinois, United States on June 9, 2017 by Brendt Christensen, a Champaign resident and former physics graduate student at the university. Due to the transnational aspect of the case coupled with the heinousness of the crime, the murder drew international headlines, and the world hung on the edge of its collective seat as the case unfolded and eventually drew to its climactic conclusion. Tried in a U.S. state that had long-declared a moratorium on the controversial death penalty, Christensen was ultimately tried, via the "commerce clause," under federal jurisdiction in which prosecutors sought capital punishment. While some in the state of Illinois decried the process, overseas, many in China espoused the appropriateness of a death sentence in this particular case, in which Ms. Zhang was brutally dismembered and her body never found. This paper examines the jurisdictional aspects of the death penalty in the U.S., scrutinizes the controversial U.S. Constitutional "commerce clause" in the context of criminal legal proceedings, elucidates the history and jurisprudential underpinnings of the death penalty in Chinese law, and discusses the psychosocial elements of Christensen's defense which certainly spared him the death penalty.
\end{abstract}

Keywords: death penalty, Chinese jurisprudence, commerce clause, U.S. Constitution, murder, homicide 